\author{
Loyalitas Kreativitas \\ Aldi Masyarakat Kreatif
}

P-ISSN 2722-2101, E-ISSN 2722-4201

Program Studi Ekonomi Manajemen Universitas Pamulang

Jurnal LOKABMAS Kreatif Vol.02,No.03.Nov 2021 Hal.94-99

Email:jurnalkreatif.manajemen@gmail.com

\title{
PEMBEKALAN KEWIRAUSAHAAN MELALUI PELATIHAN CRAFT DECOUPAGE UNTUK MENINGKATKAN KESEJAHTERAAN ANGGOTA KOPERASI KARYA CIPTA MANDIRI (KKCM) TANGERANG SELATAN
}

\author{
Sri Retnaning Sampurnaningsih, Jeni Andriani, Endang Puji Astutik, \\ Cornelia Dumarya Manik, Achmad Ludvy
}

\begin{abstract}
Dosen Prodi Sarjana Manajemen Fakultas Ekonomi dan Bisnis Universitas Pamulang
Email : dosen01366@unpam.ac.id; dosen00436@unpam.ac.id; cornelia00720@unpam.ac.id; dosen01682@unpam.ac.id; dosen02586@unpam.ac.id
\end{abstract}

\begin{abstract}
ABSTRAK
Kegiatan Pengabdian Kepada Masyarakat dengan judul Pembekalan Kewirausahaan Melalui Pelatihan Craft Decoupage untuk meningkatkan Kesejahteraan Anggota Koperasi Karya Cipta Mandiri (KKCM) Tangerang Selatan bertujuan untuk memberikan ketrampilan dan teknik pembuatan seni decoupage pada masker kain kepada anggota Koperasi Karya Cipta Mandiri (KKCM) agar dapat meningkatkan daya kreatif dan inovasi para anggota KKCM sehingga memberikan dampak positif bagi pendapatan yang pada akhirnya dapat meningkatkan kesejahteraan keluarga. Metode kegiatan yang digunakan adalah online presentasi dan tanya jawab kepada para anggota KKCM terkait pelatihan craft decoupage sebagai alternatif menambah pendapatan ekonomi keluarga. Peserta diberikan bahan pelatihan dan mengikuti pelatihan online serta langsung mempraktekan, sehingga hasil kegiatan ini adalah para peserta sudah trampil membuat seni decoupage pada masker kain.
\end{abstract}

Kata kunci: Kewirausahaan, Pelatihan, Craft, Decoupage, Kesejahteraan

\begin{abstract}
ABSTRAC
The Community Service activity with the title Entrepreneurship Debriefing Through Craft Decoupage Training to improve the Welfare of the Members of the South Tangerang Karya Cipta Mandiri Cooperative (KKCM) aims to provide skills and techniques for making art decoupage on cloth masks to members of the Karya Cipta Mandiri Cooperative (KKCM) in order to increase their productivity, creative and innovative of KKCM's member so as to have a positive impact on income which in turn can improve the welfare of the family. The activity method used is online presentation and question and answer to KKCM members regarding craft decoupage training as an alternative to increase family economic income. Participants were given training materials and participated in online training and immediately put them into practice, so that the results of this activity that the participants were skilled at making decoupage art on cloth masks.
\end{abstract}

Keywords: Entrepreneurship, Training, Craft, Decoupage, Welfare

\section{PENDAHULUAN}

Pandemi Covid-19 telah melanda Indonesia dalam waktu dua tahun ini, namun optimisme Indonesia untuk segera pulih dari pandemi sangat tinggi. Perbaikan sistem kesehatan termasuk 3T (testing, tracing, dan treatment) terus dijalankan. Percepatan vaksinasi dan refocusing yang tepat sasaran juga memberikan optimisme bahwa Indonesia akan segera kembali ke pulih lebih cepat. 
Upaya untuk menghambat penyebaran virus COVID-19 telah menghambat kegiatan perekonomian (kebijakan PPKM) dan dampaknya terhadap tingkat kesejahteraan sosial semakin dirasakan masyarakat. Setelah menunjukkan pencapaian penurunan kemiskinan beberapa tahun belakangan ini, tingkat kemiskinan kembali meningkat setelah pandemi COVID-19. Satu dari 10 orang di Indonesia hari ini hidup di bawah garis kemiskinan nasional. Tingkat kemiskinan anak juga dapat meningkat secara signifikan. Dampak negatif terhadap keadaan sosialekonomi dari pandemi bisa menjadi jauh lebih buruk tanpa adanya bantuan sosial dari pemerintah. Oleh karena ini dalam menghadapi krisis ekonomi ini, Pemerintah Indonesia telah mengeluarkan sejumlah paket stimulus fiskal skala besar melalui Program Pemulihan Ekonomi Nasional (PEN), bantuan dalam bentuk subsidi kepada para pelaku usaha, bantuan sembako dan dana untuk masyarakat berdampak secara ekonomi maupun kesehatannya.

Selain itu, dalam berkehidupan bermasyarakat dan bagian dari kewajiban Tri dharma Pendidikan, ketanggapan pada setiap lapisan masyarakat dan bagi para akademisi perlu diteruskan untuk meningkatkan kesejahteraan di masyarakat. Oleh karena itu, Kegiatan Pengabdian kepada Masyarakat (PKM) yang dilakukan oleh para dosen dan mahasiswa dari prodi Sarjana Manajemen Fakultas Ekonomi dan Bisnis Universitas Pamulang adalah membantu masyarakat dan berperan aktif untuk meningkatkan kesejahteraan. Pelaksanaan kegiatan PKM kali ini dengan judul Pembekalan Kewirausahaan melalui Pelatihan Craft Decoupage untuk Meningkatkan Kesejahteraan Anggota Koperasi Karya Cipta Mandiri (KKCM) Tangerang Selatan dilakukan setelah mengadakan survey dan wawancara dengan Ketua KKCM, Bapak Zainal Mutaqin, bahwa akibat dari pandemi dan diberlakukannya PSBB kemudian PPKM maka timbul permasalahan dan masih berlanjut, salah satunya yaitu terdampaknya sosial ekonomi dari pedagang mikro dan kecil atau UMK, pegawai yang dirumahkan, warga dengan pendididikan yang rendah, warga dengan penghasilan yang minim ataupun tidak ada pemasukan lagi. Mereka masih banyak yang belum paham tentang masa PSBB dan masih terjadi pelanggaran protap kesehatan dalam pencegahan penyebaran yang lebih meluas dari virus Corvid 19. Solusi yang diberikan terhadap permasalahan $\mathrm{KKCM}$ adalah perlu adanya penyuluhan tentang bagaimana meningkatkan pendapatan bagi para usaha mikro dan kecil dan bagaimana protap kesehatan menjadi perilaku sehari-hari warga sehingga selain membantu perekonomian di wilayahnya, juga mengurangi penderita positif Covid 19 yang pada akhirnya dapat meningkatkan kesejahteraan keluarga. Pelatihan Craft Decoupage pada media masker kain juga sebagai salah satu peluang usaha di saat pandemi dengan tetap menjaga 3M (Mencuci tangan, Memakai masker dan Menjaga jarak)

Sejalan dengan tujuan Koperasi Karya Cipta Mandiri (KKCM) untuk memberdayakan anggotanya dalam meningkatkan kesejahteraan menuju terwujudnya keluarga yang beriman dan bertaqwa kepada Tuhan yang Maha Esa, berakhlak mulia dan berbudi luhur, sehat sejahtera, maju dan mandiri, kesetaraan dan keadilan gender serta kesadaran hukum dan lingkungan.

\section{RUMUSAN MASALAH}

Dengan adanya identifikasi permasalahan yang dihadapi oleh anggota koperasi KKCM maka disusunlah rumusan masalah sebagai berikut:

1. Bagaimana memberdayakan anggota KKCM melalui pembekalan kewirausahaan?

2. Bagaimana agar anggota KKCM dapat meningkatkan kesejahteraannya melalui melalui pelatihan craft decoupage?

\section{TUJUAN PELAKSANAAN}

1. Untuk memberdayakan anggota KKCM melalui pembekalan kewirausahaan.

2. Untuk meningkatkan kesejahteraan anggota KKCM melalui pelatihan craft decoupage.

\section{TINJAUAN PUSTAKA}

\section{Pembekalan}

Pembekalan menurut arti secara bahasa dalam KBBI adalah proses, cara, perbuatan menyediakan bekal, urusan. 


\section{Kewirausahaan}

Schumpeter dalam As'ad (2002) mengemukakan bahwa wirausaha atau entrepreneur adalah seseorang yang menggerakkan perekonomian masyarakat untuk maju ke depan, mencakup mereka yang mengambil risiko,mengkoordinasi penanaman modal atau sarana produksi, yang mengenalkan fungsi faktor produksi baru atau yang mempunyai respon kreatif dan inovatif.

Suryana (2013) juga berpendapat bahwa seorang wirausaha adalah mereka yang melakukan usaha-usaha kreatif dan inovatif dengan jalan mengembangkan ide dan meramu sumber daya untuk menemukan peluang dan perbaikan hidup.

\section{Pelatihan}

Menurut Never Ending Transfusing Application Training (NET-at), Pelatihan adalah kegiatan belajar dan praktik untuk sesuatu tujuan baik, dilakukan secara berulang-ulang dan terus-menerus untuk meningkatkan kemampuan (continuously and never end) manusia, dan fitrahnya. (Cut Zurnali, 2004)

\section{Craft Decoupage}

Decoupage berasal dari bahasa Perancis découper, artinya memotong, adalah sebuah kerajinan atau bentuk seni yang memerlukan potongan-potongan bahan (biasanya kertas) yang ditempel pada objek dan kemudian dilapisi dengan beberapa lapis pernis atau pelitur. Proses itu membuat tampilan potongan-potongan kertas yang rata menjadi tampak dalam dan membuat pola dan gambar terlihat seolah-olah dilukis pada objek yang diproses dengan teknik decoupage. (wikiHow)

\section{Kesejahteraan}

Dalam istilah umum, sejahtera menunjuk ke keadaan yang baik, kondisi manusia di mana orang-orangnya dalam keadaan makmur, dalam keadaan sehat dan damai. Dalam ekonomi, sejahtera dihubungkan dengan keuntungan benda.

\section{METODE PELAKSANAAN}

Metode yang digunakan dalam kegiatan PKM ini adalah pelatihan craft decoupage kepada 15 orang anggota KKCM Tangerang Selatan. Waktu pelaksanaan tanggal 24-25 Juli 2021, secara daring/online melalui link google meet.

Kegiatan PKM terdiri dari tahap persiapan dan tahap pelaksanaan.

Tahap persiapan meliputi informasi awal, pada tahap ini didapatkan infomasi awal dari pengurus KKCM Tangerang Selatan tentang lokasi pelaksanaan dan sasaran peserta kegiatan pelatihan craft decoupage. Dikarenakan masih PPKM, pelaksanaan dilakukan secara daring/online. Berikutnya, penyusunan materi pelatihan/tutorial dan persiapan bahan praktek pelatihan craft decoupage berupa masker kain polos, tissue napkin decoupage, lem decoupage dan kuas yang dibagikan kepada peserta sebelum pelaksanaan dan peserta menyiapkan peralatan gunting sendiri.

Tahap pelaksanaan tentang pelatihan craft decoupage berupa metode demonstrasi/praktek/tutorial kepada para anggota KKCM membuat craft decoupage dengan media masker kain, Tutorial membuat masker decoupage :

1. Siapkan bahan masker kain dan peralatan decoupage

2. Menggunting kertas tissue napkin sesuai kreasi masing-masing

3. Meletakkan potongan kertas tissue untuk ditempel di atas masker kain. Biasanya kertas tissue napkin terdiri dari dua atau tiga lapisan, ambil lapisan paling atas/tipis

4. Mengoleskan lem menggunakan kuas dengan tipis dan merata pada permukaan masker yang akan ditempel kertas tissu

5. Menempelkan potongan kertas tissue napkin yang sudah dibentuk sesuai kreasi masing-masing tadi pada permukaan masker dengan hati-hati. Lalu dikeringkan.

6. Setelah kering, oleskan Kembali lem di atas permukaan tissue dengan kering supaya tidak robek lalu keringkan kembali.

7. Finishing. Selesai 


\section{HASIL DAN PEMBAHASAN}

Hasil kegiatan PKM ini bagi seluruh peserta/anggota KKCM sangat dirasakan manfaatnya karena belum pernah mendapatkan pelatihan craft decoupage sebelumnya. Dan dalam pelatihan ini peserta sangat antusias praktek langsung membuat craft decoupage dengan media masker kain walaupun pelatihannya dilakukan secara daring/online.

Dampak kegiatan pembekalan kewirausahaan melalui pelatihan craft decoupage yaitu dapat menunjukkan adanya keterampilan berkreativitas untuk meningkatkan kemampuan diri dan menjadikan peluang usaha di masa pandemi untuk meningkatkan kesejahteraan anggota KKCM Tangerang Selatan.

Pada sesi akhir diadakan tanya jawab, di mana para peserta cukup banyak yang bertanya, karena keingintahuan tentang seluk beluk craft decoupage, dan selanjutnya ditunjukkan hasil praktek masker decoupage oleh semua peserta.

Pelatihan craft decoupage ini diberikan oleh tim PKM, yang terdiri dari dosen-dosen prodi Sarjana Manajemen Universitas Pamulang dan dibantu oleh mahasiswa.

\section{KESIMPULAN DAN SARAN Kesimpulan}

1. Pembekalan Kewirausahaan memberikan dampak positif untuk meningkatkan kemampuan anggota Koperasi Karya Cipta Mandiri (KKCM) Tangerang Selatan

2. Dampak kegiatan pelatihan craft decoupage pada media masker kain dapat meningkatkan daya kreatif dan inovasi sehingga menjadi peluang usaha yang pada akhirnya dapat meningkatkan kesejahteraan anggota Koperasi Karya Cipta Mandiri (KKCM) Tangerang Selatan.

\section{Saran}

1. Perlu adanya pelatihan keterampilan kewirausahan lain untuk meningkatkan kemampuan anggota KKCM Tangerang Selatan.

2. Ditingkatkan terus peran KKCM untuk meningkatkan kesejahteraan anggotanya melalui pelatihan-pelatihan yang sesuai dengan kebutuhan saat ini, seperti pelatihan berbasis digital.

\section{DAFTAR PUSTAKA}

Andriani, Jeni, $\mathrm{R}$ Wulansari, SR Sampurnaningsih, Nofiar, F Sabina. 2020. Pemberdayaan Ibu PKK RW 05 Kelurahan Kuningan Barat Jakarta Selatan Melalui Pelatihan Manajemen Usaha Kerajinan (Craft) Decoupage Untuk Meningkatkan Ekonomi Keluarga. Jurnal Lokabmas Kreatif Vol 1 No 01

As'ad, Moh. 2002. Psikologi Industri. Yogyakarta: Liberty

Astamoen, Moko. 2005. Entrepreneurship dalam Perspektif Kondisi Bangsa Indonesia, Bandung: Alfabeta

Depdiknas. 2003. Kamus Besar Bahasa Indonesia, Edisi Ketiga, Jakarta: Balai Pustaka.

Pasaribu, V. L. D., Agrasadya, A., Shabrina, N., \& Krisnaldy, K. (2020). Menjadi Enterpreneur Muda Yang Memiliki Jiwa Leadership Untuk Menghadapi Masa Depan. Abdi Laksana: Jurnal Pengabdian Kepada Masyarakat, 1(1).

Pasaribu, V. L. D., Susanti, F., \& Hartuti, E. T. K. (2019). Memotivasi Siswa dan Siswi SMK Letris Indonesia di Dalam Menentukan Pilihan Untuk Melanjutkan Pendidikan Atau Bekerja Setelah Lulus Sekolah. Jurnal Pengabdian Dharma Laksana, 1(2), 161-172.

Pasaribu, V. L. D., Sulaiman, S., Sutiman, S., Thaharudin, T., \& Purnomo, B. Y. (2020). Pengenalan Letak Posyandu Terdekat Dikelurahan Pisangan Dengan Manajemen Pemasaran Revolusi 4.0 Untuk Meningkatkan Pengetahuan Masyarakat Letak Dan Fungsi Posyandu Terdekat Pada Kelurahan Pisangan. Dedikasi Pkm, l(1), 105-110.

Pasaribu, V. L. D., Oktrima, B., Prabowo, B., Arianto, N., \& Haryoko, U. B. (2020). Progam Pendampingan Dan Penyelenggaraan Pendidikan Anak Pada Usia Dini Terhadap Prestasi Belajar Dilingkungan Rt 020 Rw 009. Kel Giri Peni. Kec Wates. Yogyakarta. Jurnal Lokabmas Kreatif, 1(1), 71-75.

Pasaribu, V. L. D., Jannah, M., Fazar, M., Putra, S. P., Monalisa, M., \& Sofa, M. (2021). MENINGKATKAN PRODUKTIVITAS 
USAHA DIMASA PANDEMI PADA IBU PKK RT 004/003 KELURAHAN SAWAH BARU CIPUTAT, TANGERANG SELATAN. Abdi Laksana: Jurnal Pengabdian Kepada Masyarakat, 2(2), 295-301

Pasaribu, V. L. D., Yuniati, H. L., Pranata, R., Sembayu, R., Purba, S. M., \& Nurbayani, T. T. A. (2021). MANAJEMEN KEUANGAN UNTUK MENGHADAPI DAN BERTAHAN DI ERA COVID 19. Jurnal Abdimas Tri Dharma Manajemen, 2(2), 12-18.

Pasaribu, V. L. D., Dwiyatni, A., Sabina, C., Ridwan, M., Gunawan, D. D., \& Noviani, B. C. (2021). EVALUASI PENERAPAN 3M DIMASA PANDEMIC COVID 19. Jurnal Abdimas Tri Dharma Manajemen, 2(2), 54-60.

Pasaribu, V. L. D., Syafei, A. N., Farhan, A., Aufaizah, A., Irani, C., \& Firtiayani, S. R. (2021). PENGARUH DISPLIN PROTOKOL KESEHATAN TERHADAP PENCEGAHAN PENULARAN VIRUS COVID19. Jurnal Abdimas Tri Dharma Manajemen, 2(2), 91-98.

Pasaribu, V. L. D., Septiani, F., Rahayu, S., Lismiatun, L., Arief, M., Juanda, A., ... \& Rahim, R. (2021). Forecast Analysis of Gross Regional Domestic Product based on the Linear Regression Algorithm Technique.

Pasaribu, V. L. D., Priadi, A., Anismadiyah, V., Rahayu, S., \& Maduningtias, L. (2021). PENYULUHAN KREATIF DAN INOVATIF MENINGKATKAN MUTU PRODUKSI UMKM DI DESA BELEGA KABUPATEN GIANYAR. Pro Bono Jurnal Pengabdian Kepada Masyarakat, 1(02).

Pasaribu, V. L. D. (2021). PELATIHAN BERBASIS ONLINE DI ERA COVID-19. Jurnal Abdimas Tri Dharma Manajemen, 2(3), 26-32.

Pasaribu, V. L. D., \& Setyowati, R. (2021). ADAPTASI KEHIDUPAN NEW NORMAL PADA MASA PANDEMI COVID-19 DIYAYASAN PONDOK PESANTREN DAN PANTI ASUHAN NURUL IKHSAN KECAMATAN SETU, KOTA TANGERANG SELATAN. Jurnal

\author{
Lokabmas Kreatif: Loyalitas \\ Kreatifitas Abdi Masyarakat \\ Kreatif, 2(2), 82-88.
}

Priadi, A., Pasaribu, V. L. D., Virby, S., Sairin, S., \& Wardani, W. G. (2020). Penguatan Ekonomi Kreatif Berbasis Sumber Daya Desa Dikelurahan Rempoa. Abdi Laksana: Jurnal Pengabdian Kepada Masyarakat, 1(3), 356-35

Susanti, F., Ratnawati, W., \& ivan Jazwita, D. (2020). Literasi Digital Facebook dan Whatsapp terhadap Motivasi Belajar Generasi Milenial. Jurnal Lokabmas Kreatif: Loyalitas Kreatifitas Abdi Masyarakat Kreatif, 1(2), 35-40.

Susanti, F., Lisdawati, L., Andini, R., Setiawan, R., \& Ratnawati, W. (2020). Menanamkan Jiwa dan Semangat Kewirausahaan Persaingan Menghadapi di Era Globalisasi pada Guru dan Orangtua Murid Bimbingan Belajar Bimba Pamulang Tangerang Selatan. DEDIKASI PKM, 1(1), 95100.

Susanti, F., Jaswita, D. I., \& Mardiana, S. (2020). PENGEMBANGAN POTENSI EKONOMI KEWIRAUSAHAAN IBU RUMAH TANGGA DALAM MENINGKATKAN EKONOMI MASYARAKAT KELURAHAN CEMPAKA PUTIH CIPUTAT. Jurnal Lokabmas Kreatif: Loyalitas Kreatifitas Abdi Masyarakat Kreatif, 1(1), 89-95.

Suryana, 2013. Kewirausahaan Pedoman Praktis: Kiat dan Proses Menuju Sukses, Jakarta: Salemba Karya

Wulansari, Retno, J Andriani, Maswarni, F Sabina, N Oktavianti. 2021. Jurnal Abdimas Tridarma Manajemen Vol. 2 No 2

Zurnali Cut., 2004, Pengaruh Pelatihan Terhadap Perilaku Produktif karyawan. ,Bandung, Mandar Maju 
Loyalitas Kreativitas

Aldi Masyarakat Kreatif
P-ISSN 2722-2101, E-ISSN 2722-4201

Program Studi Ekonomi Manajemen Universitas Pamulang Jurnal LOKABMAS Kreatif Vol.02,No.03.Nov 2021 Hal.94-99

Email:jurnalkreatif.manajemen@gmail.com

https://id.wikipedia.org/wiki/Kesejahteraan

https://www.jurnal.id/id/blog/strategi-bisnis-

untuk-bersaing-di-era-digital/

http://www.noviawahyudi.com/2017/04/cara-

membuat-decoupage.html

https://www.tirto.id/update-corona-29 mei-

2020-di-indonesia-data-pandemi-dunia-

terkini-fDD5 tentang data update Corvid

19 di Indonesia dan di dunia

\section{DOKUMENTASI FOTO KEGIATAN}
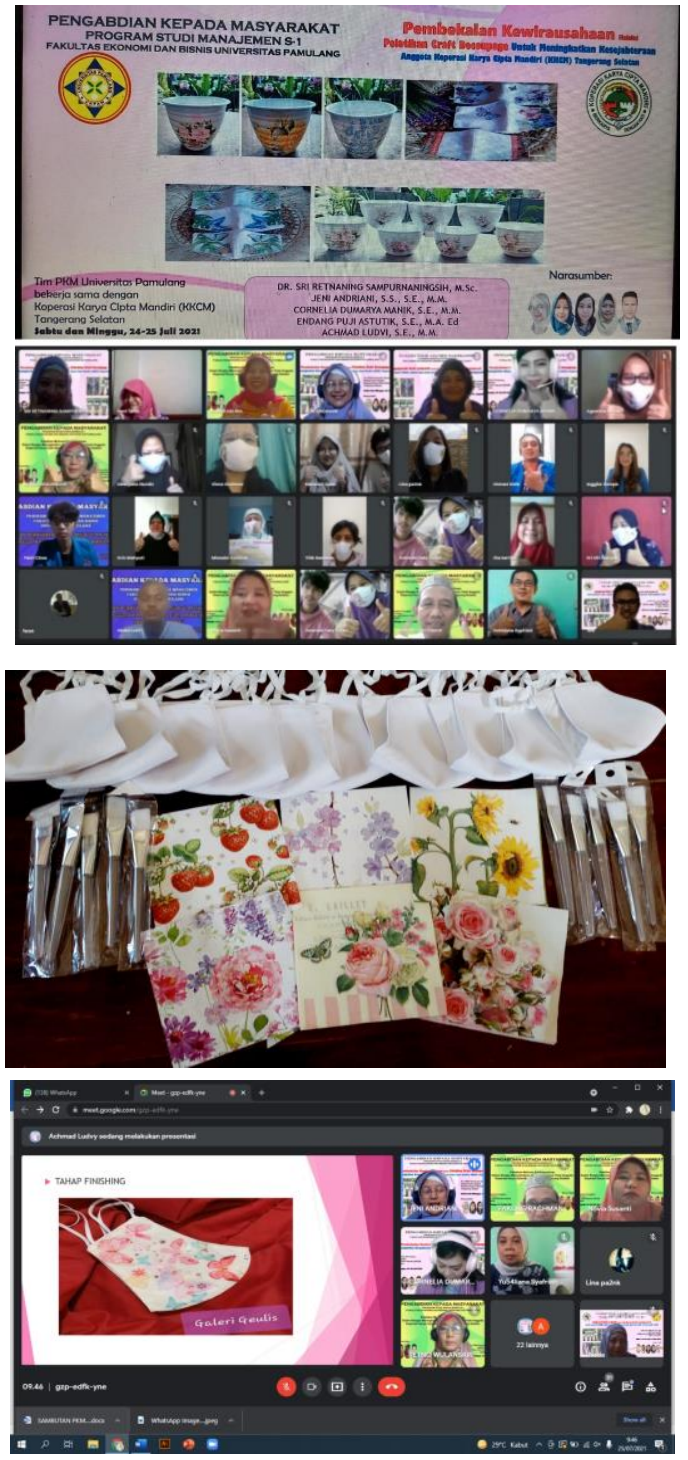